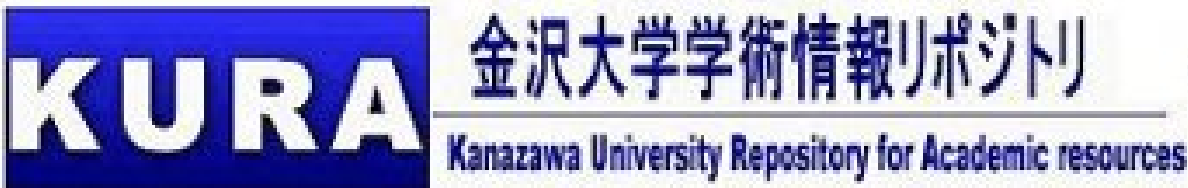

金沢大学 KANAZAWA

\begin{tabular}{|l|l|}
\hline Title & The folding type of a protein is relevant to the amino acid composition \\
\hline Author(s) & Nakashima, Hiroshi; Nishikawa, Ken; Ooi, Tatsuo \\
\hline Citation & Journal of Biochemi stry, 99(1): 153-162 \\
\hline Issue Date & 1986 \\
\hline Type & Journal Article \\
\hline Text version & publisher \\
\hline URL & http:/hdl.handle.net/2297/14560 \\
\hline Right & Copyright $\odot 1986$ Japanese Biochemical Society \\
\hline
\end{tabular}

*KURAに登録されているコンテンツの著作権は, 執筆者, 出版社 (学協会) などが有します。

*KURAに登録されているコンテンツの利用については, 著作権法に規定されている私的使用や引用などの範囲内で行ってください。

*著作権法に規定されている私的使用や引用などの範囲を超える利用を行う場合には，著作権者の許諾を得てください。ただし，著作権者 から著作権等管理事業者（学術著作権協会，日本著作出版権管理システムなど）に権利委託されているコンテンシの利用手続については ，各著作権等管理事業者に確認してください。 


\title{
The Folding Type of a Protein Is Relevant to the
}

\section{Amino Acid Composition}

\author{
Hiroshi NAKASHIMA, ${ }^{*}$ Ken NISHIKAWA, ${ }^{* *}$ and \\ Tatsuo OOI** \\ *School of Allied Medical Professions, Kanazawa University, \\ Kanazawa, Ishikawa 920, and **Institute for Chemical Research, \\ Kyoto University, Gokasho, Uji, Kyoto 611
}

Received for publication, July 20, 1985

\begin{abstract}
The folding types of 135 proteins, the three-dimensional structures of which are known, were analyzed in terms of the amino acid composition. The amino acid composition of a protein was expressed as a point in a multidimensional space spanned with 20 axes, on which the corresponding contents of 20 amino acids in the protein were represented. The distribution pattern of proteins in this composition space was examined in relation to five folding types, $\alpha, \beta, \alpha / \beta, \alpha+\beta$, and irregular type. The results show that amino acid compositions of the $\alpha, \beta$, and $\alpha / \beta$ types are located in different regions in the composition space, thus allowing distinct separation of proteins depending on the folding types. The points representing proteins of the $\alpha+\beta$ and irregular types, however, are widely scattered in the space, and the existing regions overlap with those of the other folding types. A simple method of utilizing the "distance" in the space was found to be convenient for classification of proteins into the five folding types. The assignment of the folding type with this method gave an accuracy of $70 \%$ in the coincidence with the experimental data.
\end{abstract}

Previous analyses of amino acid composition data have shown that the amino acid composition of a protein contains information about protein character: i.e., the composition has significant correlations to its biological characters: its location (inside or outside the cell), its function (enzyme or nonenzymes), it structural features, and the presence of disulfide bonds (1-3). In the present study, we focus our attention on the folding types of proteins and analyze the relation of folding type to amino acid composition. We use the same method as before of the "composition space" to represent an amino acid composition; i.e., the contents of 20 amino acids are plotted on the corresponding orthogonal axes. The dimensionality of the composition space is twenty (in the previous studies an 18-dimensional space was used). We gathered as many proteins of known sequence and three-dimensional structure as possible by surveying the literature. The previous finding that the amino acid composition has a fairly strong correlation to the folding type $(1,3)$ was reascertained with this extended data set. We will show here that the folding type of a protein is "predictable" 
in a statistical sense from its amino acid composition.

\section{METHODS}

Definition of the Composition Space-The method to express the composition of a protein as one point in the 20 -dimensional orthogonal coordinate system is to take every amino acid content on the corresponding axis. We introduce a normalized scale in order to adjust the variance of amino acid contents along an axis and make the contribution of each amino acid equivalent. A normalized composition of a protein $j$ is calculated as follows;

$$
a_{i j}=\left(c_{i j}-\overline{c_{i}}\right) / \sigma_{i}
$$

where $a_{i j}$ is the normalized content, $c_{i j}$ is the real content $(\%)$ of amino acid $i$ in the protein, and $\bar{c}_{i}$ and $\sigma_{i}$ are the average composition and standard deviation (S.D.) for amino acid $i$, respectively. The average composition of all the proteins was taken as the origin of the coordinate system, as described in the next section. The distance $d_{j k}$ between two points in the space for two proteins, $j$ and $k$, is defined in terms of their normalized compositions in a form

$$
d_{j k}=\left\{\Sigma\left(a_{i j}-a_{j k}\right)^{2}\right\}^{1 / 2}
$$

and $d_{j k}$ calculated from Eq. 2 is expressed in d.u. (distance units). A distribution of proteins in the composition space was analyzed in terms of the distance between two points (i.e., the difference in the respective amino acid compositions) and radius (a root mean squares of distances) from the center of a given cluster.

Protein Data-The definition of our composition space depends on the average composition and the standard deviations as given in Eq. 1. In order to construct it on a solid basis, $\overrightarrow{c_{i}}$ and $\sigma_{i}$ was calculated using data on 569 protein sequences which were selected by eliminating incomplete, short, and closely related sequences from our databank containing 3,010 proteins sequences. The $\sigma_{i}$ values of some residues have been adjusted by omitting proteins which have contents that deviate greatly from the mean (i.e., more than \pm 3.5 S.D. unit). Since we could determine $\overline{c_{i}}$ and $\sigma_{i}$ in this way, the composition of any protein is represented in the space.
We collected 135 proteins of known threedimensional structure for the analysis of the folding types and composition data. To avoid an artifact arising from inclusion of a number of homologous proteins, proteins were selected on the basis that they have more than 50 residues and differ by at least $50 \%$ in their sequences. The names of the selected proteins are listed in Table I. (In the table, proteins of the same family, e.g., cytochrome, are found, but the sequences differ by more than $50 \%$ as described above.)

Criteria of Assigning the Folding Type to a Protein-Proteins of known structure are usually classified into one of five folding types, $\alpha$ type, $\beta$ type, $\alpha / \beta$ type, $\alpha+\beta$ type, and irregular type, as done by Levitt and Chothia (4). We, however, encountered difficulty and ambiguity in assigning a unique type for some proteins. Thus, we introduced a quantitative measure to define a folding types by contents of $\alpha$-helix $(\alpha)$ and $\beta$-structure $(\beta)$ as follows: $\alpha$ type proteins, $\alpha>15 \%$ and $\beta<10 \%$; $\beta$ type proteins, $\alpha<15 \%$ and $\beta>10 \% ; \alpha / \beta$ type proteins, $\alpha>15 \%$ and $\beta>10 \%$ with dominantly parallel $\beta$-sheets; $\alpha+\beta$ type proteins, $\alpha>15 \%$ and $\beta>10 \%$ with dominantly antiparallel $\beta$-sheets; and irregular type proteins, $\alpha<15 \%$ and $\beta<10 \%$ In this way, the 135 proteins divided into $31 \alpha$ type, $34 \beta$ type, $39 \alpha / \beta$ type, $27 \alpha+\beta$ type, and 4 irregular type proteins. The results classified by this method are shown in Table I. The major analyses on these 135 proteins were determined irrespective of domains which are found experimentally: i.e., the folding types were determined automatically by the experimental contents of secondary structures described in the data of the Protein Data Bank (5), on the basis of the criteria described above. When the domains, the folding types of which are known, are treated as independent data, we have 202 data for the analysis. This data set was used for the test of our results.

\section{RESULTS}

Characterization of the Five Folding Groups in the Composition Space-The average compositions obtained by classification of the proteins into five folding groups are listed in Table II. There are marked differences in amino acid contents between the compositions of $\alpha$ type and $\beta$ type proteins. In order to demonstrate the differences between 
TABLE I. A list of the 135 structurally known proteins used in this work. The number of residues of a protein is given in the column "No. aa." The next column (A) gives the folding type of proteins predicted from the amino acid composition, where the irregular type is represented with " $R$." The column " PDB" indicates the identification code of the Protein Data Bank entries. Reference numbers headed by @ refer to the entry number in the table of 356 proteins in Ref. 2

\begin{tabular}{|c|c|c|c|c|c|c|}
\hline No. & Protein name & Source & No. aa & A & PDB & Ref. \\
\hline \multicolumn{7}{|c|}{$\alpha$ proteins } \\
\hline 1 & Apoferritin & Horse spleen & 175 & $\alpha$ & 0AF1 & $@ 26$ \\
\hline 2 & Bacteriorhodopsin & Halobacterium halobium & 248 & $a$ & & 12 \\
\hline 3 & Calcium-binding parvalbumin B & Carp & 108 & $\alpha$ & $1 \mathrm{CPV}$ & $@ 55$ \\
\hline 4 & Calcium-binding protein & Bovine & 75 & $\alpha$ & $1 \mathrm{ICB}$ & \\
\hline 5 & Citrate synthase & Pig heart & 437 & $\alpha / \beta$ & $1 \mathrm{CTS}$ & \\
\hline 6 & Coat protein & Tobacco mosaic virus & 158 & $\beta$ & OTMV & $@ 77$ \\
\hline 7 & Complement $\mathrm{C} 3 \mathrm{a}$ anaphylatoxin & Human serum & 77 & $\alpha+\beta$ & $0 \mathrm{C} 3 \mathrm{~A}$ & $@ 83$ \\
\hline 8 & Cytochrome $b_{562}$ & Escherichia coli & 103 & $\alpha$ & $156 \mathrm{~B}$ & @92 \\
\hline 9 & Cytochrome $c$ & Albacore tuna & 103 & $\alpha$ & $3 \mathrm{CYT}$ & $@ 93$ \\
\hline 10 & Cytochrome $c_{2}$ & Rhodospirillum rubrum & 112 & $\alpha$ & $2 \mathrm{C} 2 \mathrm{C}$ & $@ 94$ \\
\hline 11 & Cytochrome $c_{3}$ & Desulfovibrio desulfuricans & 116 & $\alpha$ & $0 \mathrm{CY} 3$ & @95 \\
\hline 12 & Cytochrome $c_{3}$ & Desulfovibrio vulgaris & 107 & $\alpha$ & $2 \mathrm{CDV}$ & \\
\hline 13 & Cytochrome $c_{5}$ & Azotobacter vinelandii & 83 & $\alpha$ & $1 \mathrm{CC} 5$ & \\
\hline 14 & Cytochrome $c_{550}$ & Paracoccus denitrificans & 121 & $a$ & $155 \mathrm{C}$ & $@ 96$ \\
\hline 15 & Cytochrome $c_{551}$ & Pseudomonas aeruginosa & 82 & $\alpha$ & $351 \mathrm{C}$ & $@ 97$ \\
\hline 16 & Cytochrome $c_{555}$ & Chlorobium thiosulfatophilum & 86 & $\alpha$ & $05 \mathrm{C} 1$ & \\
\hline 17 & Cytochrome $c^{\prime}$ & Rhodospirillum molischianum & 128 & $\alpha$ & $1 \mathrm{CCY}$ & \\
\hline 18 & Cytochrome $c$ peroxidase & Baker's yeast & 294 & $\alpha / \beta$ & $1 \mathrm{CYP}$ & $@ 99$ \\
\hline 19 & ErythrJcruorin & Chironomus thummi thummi & 136 & $a$ & $1 \mathrm{ECD}$ & (a) 114 \\
\hline 20 & Globin & Glycera dibranchiata & 147 & $a$ & OHBG & $@ 136$ \\
\hline 21 & Hemerythrin & Themiste dyscritum & 113 & $\alpha$ & $1 \mathrm{HMQ}$ & $@ 156$ \\
\hline 22 & Hemoglobin $\alpha$ chain & Horse erythrocyte & 141 & $\alpha$ & $2 \mathrm{MHB}$ & $@ 158$ \\
\hline 23 & Hemoglobin $\beta$ chain & Horse erythrocyte & 146 & $\alpha$ & $2 \mathrm{MHB}$ & $@ 159$ \\
\hline 24 & Hemoglobin & Sea lamprey & 148 & $\alpha$ & $1 \mathrm{LHB}$ & (@) 160 \\
\hline 25 & Leghemoglobin & Yellow lupin & 153 & $\alpha$ & 1LH1 & $@ 203$ \\
\hline 26 & Myoglobin & Sperm whale & 153 & $a$ & $2 \mathrm{MBN}$ & $@ 227$ \\
\hline 27 & Myoglobin & Aplysia limacina & 145 & $\alpha$ & OMBA & \\
\hline 28 & Myohemerythrin & Themiste zostericola & 118 & $a$ & $1 \mathrm{MHR}$ & (a)228 \\
\hline 29 & $\lambda$ Repressor, $\mathrm{N}$-terminal domain & Bacteriophage $\lambda$ & 92 & $a$ & OLRP & $@ 284$ \\
\hline 30 & Tropomyosin, $a$ & Rabbit skeletal muscle & 284 & $\alpha$ & & @335 \\
\hline 31 & Uteroglobin & Rabbit uterus & 70 & $a$ & OUTG & @354 \\
\hline \multicolumn{7}{|c|}{$\beta$ proteins } \\
\hline 32 & Acid proteinase & Endothia parasitica & 318 & $\beta$ & $2 \mathrm{APE}$ & \\
\hline 33 & Acid proteinase & Rhizopus chinensis & 324 & $\beta$ & $1 \mathrm{APR}$ & $@ 285$ \\
\hline 34 & Actinoxanthin & Actinomyces globisporus & 108 & $\beta$ & $1 \mathrm{ACX}$ & \\
\hline 35 & Azurin & Pseudomonas fuorescens & 128 & $\alpha$ & $1 \mathrm{AZU}$ & $@ 43$ \\
\hline 36 & Chymotrypsin A & Bovine pancreas & 245 & $\beta$ & $2 \mathrm{CHA}$ & $@ 71$ \\
\hline 37 & Coat protein & Satellite tobacco necrosis virus & 195 & $\beta$ & 2STV & \\
\hline 38 & Coat protein & Southern bean mosaic virus & 260 & $\beta$ & 3SBV & \\
\hline 39 & Coat protein & Tomato bushy stunt virus & 387 & $\beta$ & $2 \mathrm{TBV}$ & \\
\hline 40 & Concanavalin A & Jack bean & 237 & $\alpha_{i}^{\prime} \beta$ & $3 \mathrm{CNA}$ & $@ 84$ \\
\hline 41 & $\gamma$ Crystallin II & Bovine lens & 174 & $\alpha+\beta$ & OGCR & $@ 88$ \\
\hline 42 & DNA unwinding protein & Bacteriophage fd gene 5 & 88 & $\beta$ & 0GN5 & (a) 105 \\
\hline 43 & Elastase & Pig pancreas & 240 & $\dot{\beta}$ & $1 \mathrm{EST}$ & @107 107 \\
\hline 44 & Group-specific protease & Rat small intestine & 224 & $a / \beta$ & 3RP2 & $@ 152$ \\
\hline 45 & Hemagglutinin, HA1 chain & Influenza virus A Hong Kong 68 & 293 & $\beta$ & OHMG & \\
\hline
\end{tabular}

Vol. 99, No. 1, 1986 
TABLE I (Continued)

\begin{tabular}{|c|c|c|c|c|c|c|}
\hline No. & Protein name & Source & No. aa & A & PDB & Ref. \\
\hline 46 & High potential iron-sulfur protein & Chromatium vinosum & 85 & $\alpha$ & $1 \mathrm{HIP}$ & (a) 162 \\
\hline 47 & Immunoglobulin $\kappa$ Bence-Jones REI & Human patient REI & 107 & $\beta$ & 1REI & (a) 52 \\
\hline 48 & Immunoglobulin $\lambda$ Fab. L-chain & Human patient NEW & 207 & $\beta$ & $3 \mathrm{FAB}$ & $@ 179$ \\
\hline 49 & Immunoglobulin $\lambda$ Fab. H-chain & Human patient NEW & 219 & $\beta$ & $3 \mathrm{FAB}$ & $@ 180$ \\
\hline 50 & Immunoglobulin G Fc fragment & Human serum & 224 & $\beta$ & $1 \mathrm{FCl}$ & \\
\hline 51 & Kallikrein A & Pig pancreas & 232 & $\alpha / \beta$ & 2PKA & \\
\hline 52 & Long neurotoxin ( $\alpha$ cobratoxin) & Cobra (naja naja siamlnsis) & 71 & $\alpha+\beta$ & $1 \mathrm{CTX}$ & $@ 237$ \\
\hline 53 & $\alpha$-Lytic protease & Myxobacter 495 & 198 & $\beta$ & $1 \mathrm{ALP}$ & $@ 231$ \\
\hline 54 & Neuraminidase & Influlenza virus, Tokyo 367 & 469 & $\beta$ & & 13 \\
\hline 55 & Neurotoxin B (Erabutoxin B) & Broad-banded sea snake & 62 & $\beta$ & $1 \mathrm{NXB}$ & $@ 238$ \\
\hline 56 & Penicillopepsin & Penicillium janthinellum & 323 & $\beta$ & 2APP & $@ 250$ \\
\hline 57 & Pepsin & Pig stomach mucosa & 326 & $\beta$ & 1PEP & $@ 251$ \\
\hline 58 & Plastocyanin & Poplar leaves & 99 & $\alpha$ & $1 \mathrm{PCY}$ & (a) 266 \\
\hline 59 & Prealbumin & Human plasma & 127 & $\alpha / \beta$ & $2 \mathrm{PAB}$ & @267 \\
\hline 60 & Proteinase B (SGPB) & Streptomyces griseus & 185 & $\beta$ & 3SGB & $@ 277$ \\
\hline 61 & Rubredoxin & Desulfovibrio vulgaris & 52 & $\alpha+\beta$ & $3 R \times N$ & \\
\hline 62 & Scorpion venom & Centrupoides sculpturatus & 65 & $\alpha+\beta$ & $1 \mathrm{SN} 3$ & \\
\hline 63 & Superoxide dismutase, $\mathbf{C u}-\mathbf{Z n}$ & Bovine erythrocyte & 151 & $\beta$ & 2SOD & $@ 311$ \\
\hline 64 & Trypsin $\beta$ & Bovine pancreas & 223 & $\beta$ & 3РTP & $@ 339$ \\
\hline 65 & Trypsin inhibitor (Kunitz) & Soy bean & 181 & $\alpha / \beta$ & & 14 \\
\hline \multicolumn{7}{|c|}{$\begin{array}{l}65 \\
\alpha / \beta \text { proteins }\end{array}$} \\
\hline 66 & Adenylate kinase & Pig muscle & 194 & $\alpha / \beta$ & $2 \mathrm{ADK}$ & @8 \\
\hline 67 & D-Alanyl-D-alanine peptidase & Streptomyces albus & 212 & $\beta$ & 0ZGP & \\
\hline 68 & Alcohol dehydrogenase & Horse liver & 374 & $\alpha / \beta$ & $4 \mathrm{ADH}$ & (1) 15 \\
\hline 69 & Aldolase & Pseudomonas putida & 225 & $\alpha / \beta$ & $1 \mathrm{KGA}$ & $@ 262$ \\
\hline 70 & Alkaline phosphatase & Escherichia coli & 449 & $\alpha / \beta$ & & 15 \\
\hline 71 & L-Arabinose binding protein & Escherichia coli & 306 & $\alpha / \beta$ & $1 \mathrm{ABP}$ & $@ 29$ \\
\hline 72 & Aspartate aminotransferase & Chicken heart & 411 & $\alpha / \beta$ & 1AAT & \\
\hline 73 & Aspartate carbamoyltransferase C-chain & Escherichia coli & 310 & $\alpha / \beta$ & $2 \mathrm{ATC}$ & $@ 36$ \\
\hline 74 & Aspartate carbamoyltransferase R-chain & Escherichia coli & 152 & $\alpha / \beta$ & 2ATC & $@ 37$ \\
\hline 75 & Carboxypeptidase $\mathbf{A}$ & Bovine pancreas & 307 & $\alpha / \beta$ & $5 \mathrm{CPA}$ & $@ 60$ \\
\hline 76 & Carboxypeptidase $\mathbf{B}$ & Bovine pancreas & 306 & $\alpha / \beta$ & $1 \mathrm{CPB}$ & $@ 61$ \\
\hline 77 & Catalase & Bovine liver & 506 & $\alpha / \beta$ & 3CAT & $@ 65$ \\
\hline 78 & Dihydrofolate reductase & Lactobacillus casei & 162 & $\alpha / \beta$ & 3DFR & @ 321 \\
\hline 79 & Dihydrofolate reductase & Escherichia coli & 159 & $\alpha / \beta$ & 4DFR & \\
\hline 80 & Elongation factor $\mathrm{Tu}$ & Escherichia coli & 393 & $\alpha / \beta$ & OETU & @108 \\
\hline 81 & Flavodoxin & Clostridium MP & 138 & $\alpha$ & $3 \mathrm{FXN}$ & @124 \\
\hline 82 & Flavodoxin & Desulfovibrio vulgaris & 148 & $\alpha+\beta$ & OFX1 & \\
\hline 83 & D-Galactose binding protein & Salmonella typhimurium & 309 & $\alpha / \beta$ & $1 \mathrm{GBP}$ & \\
\hline 84 & Glutathione peroxidase & Bovine erythrocyte & 178 & $\beta$ & 0GP1 & (a) 145 \\
\hline 85 & Glutathione reductase & Human erythrocyte & 478 & $\alpha / \beta$ & 2GRS & $@ 146$ \\
\hline 86 & Glyceraldehyde-phosphate dehydrogenase & Lobster & 333 & $\alpha / \beta$ & 2GPD & (a) 148 \\
\hline 87 & Glycogen phosphorylase A & Rabbit skeletal muscle & 841 & $\alpha / \beta$ & OPPA & $@ 150$ \\
\hline 88 & $p$-Hydroxybenzoate hydroxylase & Pseudomonas fuorescens & 394 & $\alpha / \beta$ & OPHH & \\
\hline 89 & Lactate dehydrogenase $\mathrm{C} 4$ & Mouse testis & 329 & $\alpha / \beta$ & 1LDX & $@ 196$ \\
\hline 90 & Lactate dehydrogenase M4 & Dogfish muscle & 329 & $\alpha / \beta$ & $4 \mathrm{LDH}$ & (@) 197 \\
\hline 91 & Malate dehydrogenase (cytoplasmic) & Pig heart & 314 & $\alpha / \beta$ & $2 \mathrm{MDH}$ & $@ 218$ \\
\hline 92 & Methionyl-tRNA synthetase & Escherichia coli & 581 & $\alpha / \beta$ & 0MTS & \\
\hline 93 & Phosphofructokinase & Bacillus stearothermophilus & 316 & $\alpha / \beta$ & OPFK & $@ 255$ \\
\hline 94 & 6-Phosphogluconate dehydrogenase & Sheep liver & 466 & $\alpha / \beta$ & & 16 \\
\hline 95 & Phosphoglycerate kinase & Horse muscle & 416 & $\alpha / \beta$ & & 17 \\
\hline
\end{tabular}


TABLE I (Continued)

\begin{tabular}{|c|c|c|c|c|c|c|}
\hline No. & Protein name & Source & No. aa & A & PDB & Ref. \\
\hline 96 & Phosphoglycerate kinase & Baker's yeast & 415 & $\alpha / \beta$ & 3PGK & \\
\hline 97 & Phosphoglyceromutase & Baker's yeast & 241 & $\alpha / \beta$ & 3PGM & $@ 261$ \\
\hline 98 & Rhodanese & Bovine liver & 293 & $\alpha / \beta$ & 1RHD & $@ 324$ \\
\hline 99 & Subtilisin BPN' & Bacillus amyloliquefaciens & 275 & $\beta$ & $1 \mathrm{SBT}$ & (Q)310 \\
\hline 100 & Taka-amylase & Aspergillus oryzae & 478 & $\alpha / \beta$ & 2TAA & (d) 316 \\
\hline 101 & Thioredoxin & Escherichia coli & 108 & $\alpha / \beta$ & $1 \mathrm{SRX}$ & @ 322 \\
\hline 102 & Thioredoxin & Bacteriophage T4 & 87 & $\alpha$ & OTT4 & $@ 323$ \\
\hline 103 & Triose phosphate isomerase & Chicken muscle & 247 & $\alpha / \beta$ & $1 \mathrm{~T} 1 \mathrm{M}$ & @334 \\
\hline 104 & Tyrosyl-tRNA synthetase & Bacillus stearothermophilus & 419 & $\alpha / \beta$ & $1 \mathrm{TS} 1$ & (a) 348 \\
\hline \multicolumn{7}{|c|}{$\alpha+\beta$ proteins } \\
\hline 105 & Actinidin & Chinese gooseberry (kiwifruit) & 220 & $\beta$ & 2ACT & @5 \\
\hline 106 & $a-1-$ Antitrypsin & Human plasma & 383 & $\alpha_{/}^{\prime} \beta$ & 6API & \\
\hline 107 & Bacteriochlorophyll A protein & Chlorobium limicola & 358 & $\alpha^{\prime} \beta$ & $2 \mathrm{BCL}$ & $@ 44$ \\
\hline 108 & Carbonic anhydrase B & Human erythrocyte & 260 & $\alpha_{j}^{\prime} \beta$ & $2 \mathrm{CAB}$ & (a) 59 \\
\hline 109 & Catabolite gene activator protein & Escherichia coli & 209 & $\alpha / \beta$ & OGAP & \\
\hline 110 & Cytochrome $b_{5}$ & Bovine liver & 93 & $a$ & $2 \mathrm{~B} 5 \mathrm{C}$ & $@ 91$ \\
\hline 111 & Deoxyribonuclease I & Bovine pancreas & 257 & $\alpha / \beta$ & & 18 \\
\hline 112 & DNA binding protein II & Bacillus stearothermophilus & 90 & $\alpha$ & & 19 \\
\hline 113 & Hemagglutinin, HA2 chain & Influenza virus A Hong,Kong 68 & 8293 & $\alpha / \beta$ & OHMG & \\
\hline 114 & Inorganic pyrophosphatase & Baker's yeast & 285 & $\alpha / \beta$ & 1PYP & @ 182 \\
\hline 115 & Lysozyme & Chicken egg white & 129 & $\alpha+\beta$ & $2 \mathrm{LYZ}$ & $@ 212$ \\
\hline 116 & Lysozyme & Bacteriophage T4 & 164 & $\alpha / \beta$ & 1LZM & $@ 213$ \\
\hline 117 & Ovomucoid, third domain & Japanese quail & 56 & $\alpha+\beta$ & $10 \mathrm{VO}$ & $@ 244$ \\
\hline 118 & Pancreatic secretory trypsin inhibitor & Pig pancreas & 56 & $\alpha+\beta$ & 1TGS & \\
\hline 119 & Papain & Papaya & 212 & $\alpha+\beta$ & 8PAP & (a) 247 \\
\hline 120 & Phospholipase $\mathbf{A}_{2}$ & Porcine pancreas & 124 & $\alpha+\beta$ & 1P2P & $@ 273$ \\
\hline 121 & cro Repressor & Bacteriophage $\lambda$ & 66 & $\alpha$ & OCRO & \\
\hline 122 & Ribonuclease A & Bovine pancreas & 124 & $\alpha+\beta$ & 4RSA & (a) 287 \\
\hline 123 & Ribonuclease (Barnase) & Bacillus amyloliquefaciens & 110 & $\beta$ & ORNB & \\
\hline 124 & Ribonuclease ST & Streptomyces erythreus & 101 & $a+\beta$ & ORST & \\
\hline 125 & Ribonuclease $T_{1}$ & Aspergillus oryzae & 104 & $\alpha+\beta$ & ORNT & (a) 288 \\
\hline 126 & Ribosomal protein $\mathbf{L} 7 / \mathrm{L} 12$ & Escherichia coli & 120 & $\alpha$ & OCTF & $@ 293$ \\
\hline 127 & Staphylococcal nuclease & Staphylococcus aureus & 149 & $\alpha / \beta$ & 2SNS & $@ 221$ \\
\hline 128 & Streptomyces subtilisin inhibitor & Streptomyces albogriseolus & 113 & $\beta$ & 2SSI & $@ 309$ \\
\hline 129 & Superoxide dismutase, $\mathrm{Mn}$ & Escherichia coli & 205 & $\alpha / \beta$ & OSDE & $@ 312$ \\
\hline 130 & Thermolysin & Bacillus thermoproteolyticus & 316 & $\alpha+\beta$ & $3 T L N$ & $@ 54$ \\
\hline 131 & Trypsin inhibitor, BPTI & Bovine pancreas & 58 & $\alpha+\beta$ & 4PTI & $@ 341$ \\
\hline \multicolumn{7}{|c|}{ Irregular type proteins } \\
\hline 132 & Agglutinin isolectin 2 & Wheat germ & 171 & $\mathbf{R}$ & $2 \mathrm{WGA}$ & 20 \\
\hline 133 & Ferredoxin, bacterial-type & Peptococcus aerogenes & 54 & $\mathbf{R}$ & IFDX & $@ 117$ \\
\hline 134 & Ferredoxin, chloroplast-type & Spirulina platensis & 98 & $\alpha+\beta$ & $3 \mathrm{FXC}$ & (a) 118 \\
\hline 135 & Ferredoxin & Azotobacter vinelandii & 106 & $\alpha+\beta$ & 2FD1 & \\
\hline
\end{tabular}

them, deviations from the corresponding average content for every amino acid normalized with the S.D. values were calculated for $\alpha$ type and $\beta$ type proteins. As shown in Fig. 1, deviations obtained on the $\alpha$ type proteins are in the opposite direction to those on the $\beta$ type proteins for most of amino acids; exceptional amino acids are Arg, Ile, and Cys. Positive deviations of Lys, Ala, His, Asp, Met, Leu, Phe, Glu, and Cys are observed in the $a$ type proteins, while Ser, Cys, Thr, Gly, Pro, Trp, Asn, Val, Tyr, and Gln are amino acids of positive deviations for the $\beta$ type proteins. A 
TABLE II. The average amino acid composition (AV) and standard deviation (S.D.) of the total proteins, and the average composition of the five folding types, $\alpha, \beta, \alpha / \beta, \alpha+\beta$, and the irregular, $\mathbf{R}$ (all the data are in molar percent, $\%$ ). In the two sets of values given for each folding type (except for $\mathrm{R}$ ), the former one is the average over the proteins included in a given type, and the latter is the corresponding one obtained by optimization so as to yield the best prediction of the folding type (see the text). The total average and S.D. were determined by using data for 569 proteins (see "METHODS").

\begin{tabular}{lrrrrrrrrrrr}
\hline Amino acid & AV & \multicolumn{1}{c}{ S.D. } & \multicolumn{2}{c}{$a$} & \multicolumn{2}{c}{$\beta$} & \multicolumn{2}{c}{$a / \beta$} & \multicolumn{1}{c}{$a+\beta$} & \multicolumn{1}{c}{ R } \\
\hline Ala & 8.74 & 3.67 & 11.63 & 11.67 & 7.54 & 8.29 & 8.83 & 9.19 & 8.89 & 9.12 & 8.90 \\
Cys & 1.62 & 1.53 & 1.71 & 1.81 & 3.48 & 3.51 & 1.43 & 1.77 & 2.94 & 3.97 & 12.04 \\
Asp & 5.72 & 2.20 & 6.52 & 6.47 & 5.37 & 4.98 & 6.12 & 6.59 & 5.76 & 4.05 & 8.85 \\
Glu & 6.39 & 2.88 & 6.52 & 6.56 & 3.75 & 3.81 & 6.12 & 6.61 & 6.18 & 5.12 & 6.85 \\
Phe & 3.87 & 1.85 & 4.22 & 4.30 & 3.57 & 3.67 & 3.88 & 3.38 & 3.60 & 3.01 & 1.73 \\
Gly & 7.82 & 2.98 & 7.66 & 7.05 & 9.87 & 9.65 & 8.71 & 8.91 & 8.00 & 7.99 & 10.49 \\
His & 2.15 & 1.32 & 2.79 & 2.59 & 1.64 & 2.04 & 2.19 & 2.27 & 2.00 & 1.25 & 1.02 \\
Ile & 5.15 & 2.29 & 3.72 & 3.72 & 4.76 & 4.63 & 5.82 & 5.71 & 4.74 & 4.85 & 6.99 \\
Lys & 6.78 & 3.34 & 10.10 & 10.00 & 4.66 & 4.82 & 6.55 & 6.75 & 7.18 & 5.95 & 3.27 \\
Leu & 8.20 & 3.16 & 8.89 & 9.18 & 6.69 & 6.36 & 8.54 & 8.09 & 6.37 & 5.21 & 4.02 \\
Met & 2.08 & 1.26 & 2.42 & 2.15 & 1.24 & 1.47 & 2.14 & 2.07 & 1.40 & 0.62 & 0.53 \\
Asn & 4.39 & 1.99 & 3.79 & 3.99 & 4.90 & 4.65 & 4.13 & 4.35 & 5.60 & 7.31 & 4.16 \\
Pro & 4.49 & 2.04 & 3.81 & 3.79 & 5.23 & 6.03 & 4.36 & 4.21 & 4.29 & 4.88 & 5.82 \\
Gln & 3.91 & 1.74 & 3.33 & 3.48 & 4.12 & 3.99 & 3.44 & 3.46 & 3.17 & 3.33 & 4.03 \\
Arg & 4.81 & 2.53 & 2.79 & 3.12 & 3.22 & 3.98 & 4.35 & 4.08 & 4.05 & 3.14 & 1.08 \\
Ser & 6.56 & 2.73 & 5.44 & 6.17 & 9.50 & 9.14 & 5.89 & 5.34 & 7.05 & 8.04 & 6.42 \\
Thr & 5.84 & 2.30 & 4.91 & 4.41 & 7.83 & 7.42 & 5.50 & 4.52 & 6.41 & 8.26 & 4.35 \\
Val & 7.01 & 2.48 & 6.02 & 5.59 & 7.48 & 6.70 & 7.62 & 7.77 & 6.50 & 6.54 & 4.89 \\
Trp & 1.17 & 0.98 & 1.17 & 1.30 & 1.48 & 1.35 & 1.38 & 1.37 & 1.28 & 1.22 & 0.62 \\
Tyr & 3.33 & 1.87 & 2.55 & 2.64 & 3.67 & 3.41 & 3.02 & 2.66 & 4.59 & 6.14 & 3.95 \\
\hline
\end{tabular}

similar tendency is seen for amino acids with negative deviations (Fig. 1). Apparently, an amino acid composition of an $a$ type protein is different from that of a $\beta$ type protein.

The distribution of points representing proteins of one folding type in the composition space may be characterized by the location of a center (i.e., an average composition) and the root-mean squares (rms) radius of the distribution for the folding type from the center. The distance to the origin and the rms radius (both in d.u.) are (2.04, 5.26), (2.62, 4.95), (0.77, 3.38), (1.65, 5.08), and $(9.69,6.47)$ for proteins of $\alpha$ type, $\beta$ type, $\alpha / \beta$ type, $\alpha+\beta$ type, and irregular type, respectively. The distribution of the $\alpha / \beta$ type proteins is narrowest, having its center near the origin as indicated by a short distance to the origin $(0.77$ d.u) and a small rms radius (3.38 d.u.). Compositions of irregular-type proteins, though the number of data is small, locate far away from the origin ( 9.69 d.u.).

In order to illustrate the distribution, points in the composition space were projected onto a plane which is defined by two vectors, one pointing from the average composition of the $\alpha+\beta$ type proteins to that of the $\alpha$ type proteins (vector A) and the other from the $\alpha+\beta$ type to the $\beta$ type (vector B). The projection on the plane was done in a way similar to the previous method $(1,3)$. As the angle between the $\mathrm{A}$ and $\mathrm{B}$ vectors was $107.6^{\circ}$, the $X$ axis was taken in the direction of the $A$ vector from the origin and the $\mathrm{Y}$ axis was chosen so as to be perpendicular to the $X$ axis in the plane defined with the vectors $\mathrm{A}$ and $\mathrm{B}$ both pass- 


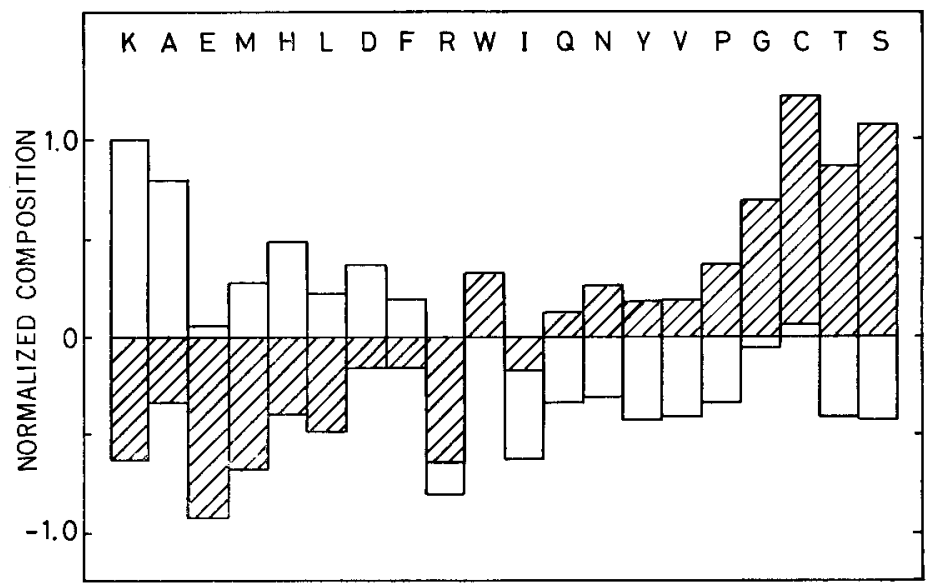

Fig. 1. Comparison of the average composition between the $\alpha$ and $\beta$ type proteins. The normalized composition is used in accordance with Eq. 1, so that the value plotted indicates the deviation from the total average. Open columns are used for the $\alpha$ type and shaded columns for the $\beta$ type. Amino acids are denoted by the one-letter code.

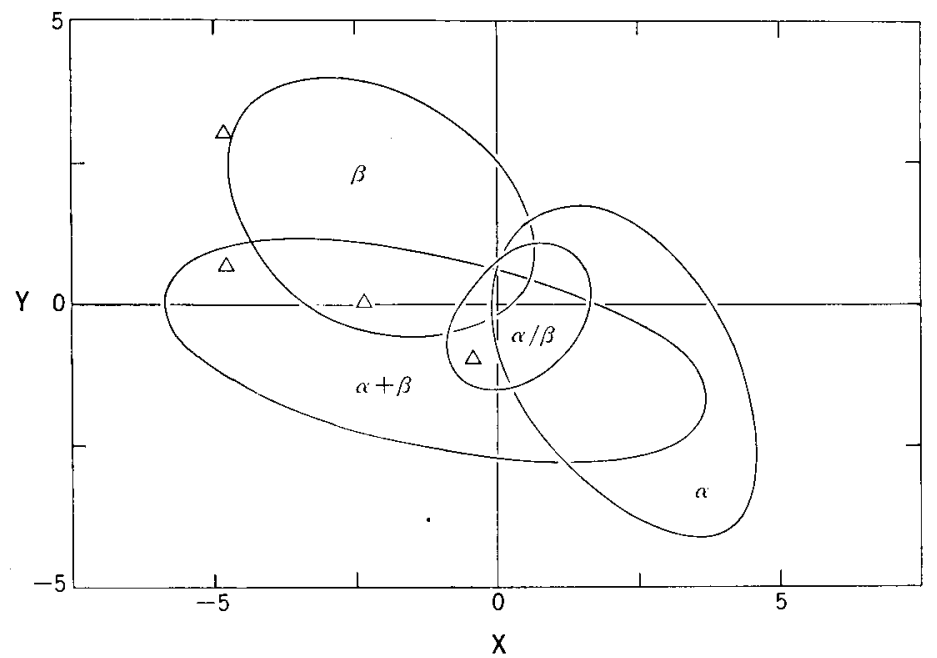

Fig. 2. Schematic drawing of the distribution pattern of the four $(\alpha, \beta, \alpha / \beta$, $\alpha+\beta$ ) types of proteins projected onto a plane. The $\mathrm{X}$ axis represents the $\alpha$ helical character and $\mathrm{Y}$ approximately represents $\beta$-sheet character (see the text). The origin was taken at the total average composition. The four irregular-type proteins are plotted with the symbol $\Delta$. There are some exceptional proteins which fall outside the individual regions indicated. The number of such proteins are: 2 out of 31 proteins for the type $\alpha, 3$ out of 34 for $\beta, 7$ out of 39 for $\alpha / \beta$, and 3 out of 27 for $\alpha+\beta$.

ing through the origin. Thus, the $X$ axis represents the $\alpha$-helical character and the $\mathrm{Y}$ axis approximately the $\beta$-sheet character (17.6 from the $B$ vector).
Figure 2 shows the resulting distribution of proteins schematically, indicating that the amino acid compositions of proteins which belong to the same folding type locate in a specified region of 
the space. Proteins of the irregular type seem to scatter in the extended direction of the $\alpha+\beta$ and $\beta$ regions (the points are shown in Fig. 2). The regions of $a$ and $\beta$ types appear almost completely separated from each other, while the $\alpha / \beta$ and $\alpha+\beta$ regions seem to overlap with the other regions. The actual overlap in the composition space is, however, not so serious as expected from the appearance, since Fig. 2 is just a two-dimensional representation of the distribution. The degree of overlap (or separation) quantitatively shown below demonstrates that distinction among $\alpha, \beta$, and $\alpha /$ $\beta$ is good in practice.

Classification of Proteins into Folding Groups by Their Compositions-Since points representing proteins of the same folding type cluster in the composition space as shown in Fig. 2, it is possible to classify proteins into five folding types according to their amino acid compositions. There are two ways to assign the folding type of a protein according to its amino acid composition. One method is as follows: proteins whose composition is located beyond a distance greater than 11 d.u. from the origin are assigned as the irregular type. A protein is assigned as an $\alpha / \beta$ type one when its composition locates smaller than 3.91 d.u. from the center of $\alpha / \beta$ type proteins. The folding type of a protein which does not meet the above conditions is determined by the criterion of the shortest distance to the centers of the $\alpha, \beta$, and $\alpha+\beta$ types, respectively. In this way, folding types of proteins are automatically assigned in terms of dis- tances measured in the composition space. The theoretical folding types are shown in column A in Table I and the comparison of this classification with that based on secondary structures determined experimentally from X-ray analysis is summarized in Table III(a). The numbers on the diagonal represent proteins for which the theoretical analysis coincides with experimental data. The score of the agreement is $70 \%(94 / 135)$, and this is equivalent to a measure of separation of the different types in the composition space. The worst distinction is seen between the $\alpha+\beta$ and $\alpha / \beta$ types. When these two types were unified and the classification was made into the three types of $\alpha, \beta$, and " $\alpha \beta$ complex" (excluding irregular type), the score of coincidence increased to $80 \%(105 / 131)$.

The other method is to use the criterion of the shortest distance to a group center; i.e., the distance from the origin is first computed, and then the distances to the four centers of the folding types are compared. When the distance from the origin is greater than $11 \mathrm{~d} . \mathrm{u}$., the protein is assigned as the irregular type as done before. If not, the closest folding type is selected as that for the protein. Since only distances are used for the criterion, the latter method is simpler than the former method. Since we don't have so much data for proteins whose folding types is known, we have to optimize the location of the "centers" of corresponding folding types. Numbers shown in parentheses of Table III(a) are the results obtained by the latter method using optimized aver-

TABLE III. Comparison of the two classifications of folding types, one based on the amino acid composition (column) and the other from X-ray observation (row). (a) Comparison for 135 proteins. The numbers in parentheses show the result when the optimized composition (Table II) is used as the "center" of each protein group. (b) Comparison for 202 domains. The optimized composition (Table II) is used as the "center" of each protein group.

\begin{tabular}{|c|c|c|c|c|c|c|c|c|c|c|c|c|c|}
\hline & \multicolumn{5}{|c|}{ (a) Observed type } & \multirow{2}{*}{ Total } & & \multicolumn{5}{|c|}{ (b) Observed type } & \multirow{2}{*}{ Total } \\
\hline & $\alpha$ & $\beta$ & $\alpha / \beta$ & $\alpha+\beta$ & $\mathrm{R}$ & & & $\alpha$ & $\beta$ & $\alpha / \beta$ & $\alpha+\beta$ & $\mathrm{R}$ & \\
\hline$a$ & $27(28)$ & $3(2)$ & $2(0)$ & $4(7)$ & $0(0)$ & $36(37)$ & $\alpha$ & 30 & 2 & 0 & 8 & 0 & 40 \\
\hline$\beta$ & $1(1)$ & $22(26)$ & $3(4)$ & $3(3)$ & $0(0)$ & $29(34)$ & $\beta$ & 3 & 51 & 6 & 3 & 1 & 64 \\
\hline$\alpha / \beta$ & $2(2)$ & $5(4)$ & $33(33)$ & $10(5)$ & $0(1)$ & $50(45)$ & $\alpha / \beta$ & 6 & 7 & 49 & 10 & 1 & 73 \\
\hline$\alpha+\beta$ & $1(0)$ & $4(2)$ & $1(2)$ & $10(12)$ & $2(1)$ & $18(17)$ & $\alpha+\beta$ & 2 & 5 & 2 & 13 & 1 & 23 \\
\hline $\mathbf{R}$ & $0(0)$ & $0(0)$ & $0(0)$ & $0(0)$ & $2(2)$ & $2(2)$ & $\mathbf{R}$ & 0 & 0 & 0 & 0 & 2 & 2 \\
\hline Total & 31 & 34 & 39 & 27 & 4 & 135 & Total & 41 & 65 & 57 & 34 & 5 & 202 \\
\hline
\end{tabular}


age compositions of every folding type, which are listed in the second column of Table II. The score is $(101 / 135)$, or $75 \%$. This value is not surprising because we optimized the average compositions of each folding type to get a better score. The test of this method should be done for an expanded data set; e.g., we have data on domains of several proteins listed in Table I, which are available for the test of the method. Table III(b) shows that the score is $(145 / 202)$ or $71 \%$. Therefore, we have a similar prediction score of about $70 \%$ by the use of both methods.

When we optimized the average compositions again for the expanded data set, we did not obtain any improvement on the score, indicating that the values in Table II are already at the optimum.

\section{DISCUSSION}

The present analyses indicate that proteins of the same folding type have amino acid compositions which locate within a specified region in the composition space. The four regions are well separated from each other, except for that of the $a+\beta$ type (see above). In other words, proteins of every folding type are characterized by their amino acid compositions; the differences in amino acid contents of $a$ type and $\beta$ type proteins shown in Fig. 1 are examples. At a glance, one might feel that the relative abundance or scarcity of amino acids plotted in Fig. 1 is not consistent with the wellknown propensity of amino acids to form $\alpha$-helix or $\beta$-structure (6-8), particularly so for $\beta$-proteins. However, what is shown in Fig. 1 is the difference in the "whole" compositions between $\alpha$ type and $\beta$ type proteins. If we look at the difference, i.e., the total length of a column of each amino acid, and take account of the fact that $\beta$ type proteins usually contain many more turns and irregular conformations than $a$ proteins, the data shown in Fig. 1 would be attributed to the reflection of the properties of single amino acids.

This result has an important meaning: properties of single amino acid residues are, as the first approximation, additive regardless of the sequence. The nature of a protein as a whole is, therefore, approximately determined by its amino acid composition. Moreover, analysis using the composition space should be a useful tool for general analyses of proteins.
As described before, we introduced a quantitative criterion using the amount of $\alpha$-helix and $\beta$-structure for classifying proteins from the X-ray data. The present assignment of folding types (Table I) is more objective, and therefore better than those in the previous study (the Table in the appendix of Ref. 2), where a few proteins were assigned differently (i.e., 18, 46, 126, 128, and 134 by the serial number in Table I).

Busetta and Barrans ( 9 ) have recently reported a prediction study of protein types, $\mathrm{A}, \mathrm{B}$, and $\mathrm{AB}$, corresponding to our $\alpha, \beta$ and the unified type of $\alpha / \beta$ and $\alpha+\beta$. They employed the sequence data and made the prediction using a single quantity, which was derived from a predictive function developed for secondary structures of a protein (10). If the present assignment based on the X-ray data (Table I) is replaced by theirs and the comparison is made with their prediction, the score of coincidence becomes $79 \%$ (i.e., 41/52), comparable with our result in the case of using the three folding types, $\alpha, \beta$, and $\alpha \beta$ complex. This result again suggests that a considerable amount of information is obtained from the composition data.

Generally, it is difficult to make an unequivocal assignment of the folding type to a protein. The best way would be to divide a protein molecule into folding units, namely domains, as has been done by Richardson (11). When we know the domains in the three-dimensional structure of a protein, then we can examine the correlation between sequence and folding type, as shown in Table III(b). On the other hand, it is not possible to assign domains according only to the amino acid sequence at the present stage. Therefore, the problem of how to determine the domain arises.

Since the regions corresponding to each folding type are separated from each other in the composition space, it might be possible to get better separation if we use amino acid pairs instead of a single residue; i.e., the 400 -dimensional space might give better clustering of points which represent proteins of the same folding type. As far as we tried, we could not find any tendency toward clustering in the 400-dimensional space. Presumably, the meaning of a "sequence" appears already in doublet, triplet, and so on. 
One of the authors (H.N.) expresses his thanks for the fellowship given by the Ministry of Education, Science and Culture of Japan for a leave from Kanazawa University to stay at the Institute for Chemical Research, Kyoto University, in 1984.

\section{REFERENCES}

1. Nishikawa, K. \& Ooi, T. (1982) J. Biochem. 91, 1821-1824

2. Nishikawa, K., Kubota, Y., \& Ooi, T. (1983) J. Biochem. 94, 981-995

3. Nishikawa, K., Kubota, Y., \& Ooi, T. (1983) $J$. Biochem. 94, 997-1007

4. Levitt, M. \& Chothia, C. (1976) Nature 261, 552558

5. Bernstein, F.C., Koetzle, T.F., Williams, G.J.B., Meyer, E.F., Jr., Brice, M.D., Rodgers, J.R., Kennard, O., Shimanouchi, T., \& Tasumi, M. (1977) J. Mol. Biol. 112, 535-542

6. Chou, P.Y. \& Fasman, G.D. (1978) Annu. Rev. Biochem. 47, 251-276

7. Levitt, M. (1978) Biochemistry 17, 4277-4285

8. Lifson, S. \& Sander, C. (1979) Nature 282, 109-111
9. Busetta, B. \& Barrans, Y. (1984) Biochim. Biophys. Acta 790, 117-124

10. Busetta, B. \& Hospital, M. (1982) Biochim. Biophys. Acta 701, 111-118

11. Richardson, J.S. (1981) Adv. Protein Chem. 35, 167-339

12. Leifer, D. \& Henderson, R. (1983) J. Mol. Biol. 163, 451-466

13. Varghese, J.N., Laver, W.G., \& Colman, P.M. (1983) Nature 303, 35-44

14. McLachlan, A.D. (1979) J. Mol. Biol. 133, 557-563

15. Sowadski, J.M., Foster, B.A., \& Wyckoff, H.W. (1981) J. Mol. Biol. 150, 245-272

16. Adams, M.J., Archibald, I.G., Helliwell, J.R., \& Jenkins, S.E. (1978) Acta Crystallogr. 34, S64

17. Banks, R.D., Blake, C.C.F., Evans, P.R., Haser, R., Rice, D.W., Hardy, G.W., Merrett, M., \& Phillips, A.W. (1979) Nature 279, 773-777

18. Suck, D., Oefner, Ch., \& Kabsch, W. (1984) EMBO J. 3, 2423-2430

19. Tanaka, I., Appelt, K., Dijk, J., White, S.W., \& Wilson, K.S. (1984) Nature 310, 376-381

20. Wright, C.S., Gavilanes, F., \& Peterson, D.L. (1984) Biochemistry 23, 280-287 